\title{
NOTAS PARA UMA TEORIA DO "VIRAR BRANCO" *
}

José Antonio Kelly

\begin{abstract}
"Agora somos 'civilizados"'; "eles vivem como os antigos costumavam viver". Afirmações desse tipo são comuns entre os Yanomami que vivem nas proximidades das missões e dos postos de saúde ao longo do Orinoco, a primeira a propósito de si mesmos e a segunda a respeito de seus compatriotas rio acima. Para muitos dos médicos e outros agentes não-indígenas que atuam na região, esses comentários soam como evidência de "perda cultural", de deterioração de um estado prístino de indianidade agora contaminado por valores ocidentais.
\end{abstract}

Mesmo que a literatura etnográfica amazônica, histórica e contemporânea nos brinde com vários exemplos de índios expressando-se em termos similares — os Tupinambá quinhentistas (Viveiros de Castro 2001), os Piro peruanos (Gow 2001), os Huaroani do Equador (Rival 2002), para mencionar apenas alguns - , os antropólogos, com umas poucas notáveis exceções (Gow 1993; 2001; Rival 2002), não deram muita atenção a essas afirmações do ponto de vista da constituição do mundo vivido daqueles que as expressam.

Paralelamente a esse relativo silêncio, a produção antropológica sobre os índios sul-americanos desenvolveu-se, como observou Turner (1987), em duas direções. De um lado, elaborou-se um considerável corpus teórico a partir do estudo de temas clássicos como o parentesco, o xamanismo, e a guerra. O fato de que um certo número de conceitos, tais como os de "perspectivismo" ou de "afinidade potencial", veja-se hoje incorporado ao nosso vocabulário sem que maiores explanações se façam necessárias é sintoma do desenvolvimento de uma teoria especificamente amazônica. Na outra direção, privilegiou-se o problema do envolvimento dos povos indígenas com seus respectivos Estados nacionais e prestou-se particular atenção à "política da identidade" e a tudo que evidenciasse processos de mudança — social, cultural, econômica ou política. Aqui, as palavras-chave são "identidade", "multiculturalismo", "mudança". 
Essa literatura tem florescido de modo relativamente independente da teorização desenvolvida em circunstâncias mais "tradicionais". Comparativamente, ela também parece carecer de uma espinha dorsal teórica, produzida a partir da síntese dos diversos processos históricos vividos pelos povos amazônicos. No cruzamento entre "o tradicional" e "o moderno" de um lado, e "teoria geral" e "casos individuais" de outro, somos aparentemente deixados diante de uma "teoria tradicional" que ignora processos "modernos", ao lado de um conjunto de "casos modernos" carentes de uma teoria enraizada na síntese da etnografia.

O objetivo deste artigo é dar início a uma discussão que enfrente essas carências e lance pontes sobre essas fraturas. É tão necessário para a teoria amazônica pôr-se à prova das circunstâncias modernas, quanto para a literatura das relações com o Estado tomar mais seriamente em conta os traços particularmente amazônicos das relações mantidas ao longo das redes que incluem diferentes categorias de índios e brancos. Uma análise do "virar branco" - um fenômeno consideravelmente difundido na região, produto de um contato interétnico diversificado, que ocorre em cenários diversos (envolvendo missionários e políticos, educação formal, sistemas de saúde, redes econômicas) — constitui uma oportunidade para gerar proposições capazes de dar a esses "cenários modernos" uma resposta teórica à altura daquela desenvolvida em contextos tradicionais.

Desde já, deixo claro não acreditar que a vida amazônica contemporânea - que mescla xamanismo, espíritos auxiliares e partidos políticos; demônios canibais predadores de corpos indígenas e parasitas da malária sob o microscópio; conselhos de velhos e reuniões com representantes do Estado - possa ser analisada de modo adequado, sem levar seriamente em consideração a "teoria tradicional". Este artigo procura salientar essa necessidade. Por outro lado, e da mesma maneira, considerar o "virar branco" como um processo de "perda cultural" ou "contaminação" não apenas consiste em uma hiper-simplificação, como também implica uma avaliação baseada em uma noção euro-americana de cultura que, penso, não é transferível para nossos interlocutores indígenas.

Meu próprio trabalho de campo, voltado para a articulação do sistema venezuelano de saúde com as comunidades yanomami, logo me obrigou a contemplar temas situados fora dessa esfera. Na relação entre médicos, pacientes e comunidade, as implicações do fato de os médicos serem napë (brancos) e os pacientes serem yanomami sobredeterminavam quaisquer outras divergências previsíveis quanto ao sistema médico e teorias da doença. Esses tópicos, normalmente considerados o centro da questão nas relações entre médicos e comunidades indígenas, são, argumentarei, totalmente secundários 
tanto do ponto de vista do esforço dos Yanomami para colocar os médicos e o sistema de saúde a serviço de seu projeto de "virar branco", quanto do ponto de vista das reações dos médicos relativamente a esse esforço.

Suspeito que a análise das relações com outros serviços públicos (por exemplo, educação) ou organizações políticas deva, de modo similar, iluminar o significado cotidiano das relações com os brancos e o Estado. É meu objetivo oferecer, neste artigo, algumas idéias e reflexões que possam vir a ter valor teórico em outros contextos de relações entre brancos e índios, em diferentes partes da Amazônia.

\section{O cenário}

Este artigo se baseia em minha experiência de campo entre os Yanomami do alto Orinoco, no contexto de relações tecidas em torno da operação do sistema de saúde - um punhado de postos construídos junto a missões religiosas, onde trabalham médicos brancos (recém-formados) e enfermeiros, microscopistas e pilotos de barco yanomami.

Os Yanomami habitam uma área da seção ocidental da fronteira entre a Venezuela e o Brasil. A população total de Yanomami na Venezuela, segundo um censo indígena de 1992, é de aproximadamente 15 mil pessoas. Dessas, 13.500 Yanomami (Yanomami e, em menor extensão, Sanumá) habitam o estado do Amazonas, a maior parte deles no município do Alto Orinoco ${ }^{1}$.

Trabalhei em Ocamo, um conglomerado de dez comunidades nas proximidades de uma missão salesiana e de um posto de saúde mantido pelo Estado, nas margens de um rio do mesmo nome. As comunidades reúnem, cada uma, entre 7 e 75 moradores, e o total aproxima-se de 370. Ocamo dispõe de um serviço de saúde permanente, de uma escola bilíngüe intercultural - que vai até a 6a série - e de uma cooperativa econômica, Shaponos Unidos Yanomami del Alto Orinoco (SUYAO), que fornece bens manufaturados (machetes, panelas, tecido, linha de pesca e anzóis, sabão, lâmpadas etc.) em troca de dinheiro ou produtos indígenas (cestos, flechas). Algumas mulheres trabalham costurando ou fazendo redes de nylon; uma espécie de "lado feminino" da cooperativa. Ocamo conta também com uma pista de pouso, utilizada principalmente para vôos relacionados ao sistema de saúde - transporte de pacientes para a capital do estado, Puerto Ayacucho, ou de pessoal e suprimentos para Ocamo. Como se pode ver, trata-se de um cenário similar ao de muitas aldeias amazônicas.

A área de influência do posto de saúde estende-se rio acima, incluindo uma série de comunidades cuja comparação com o conglomerado de 
Ocamo permite perceber a existência de um importante "gradiente de trocas" com o mundo dos brancos.

Seis horas a montante, a comunidade de Pashopeka não dispõe de armas de fogo, motores de barco ou pessoas que falem espanhol. Segundo um survey que realizei ali, apenas duas entre 36 pessoas já haviam descido o rio até La Esmeralda (a localidade multi-étnica mais próxima, de estilo ocidental), e nenhuma jamais saíra do Alto Orinoco. Em comparação, no conglomerado de Ocamo existem 36 espingardas e 16 motores, a maior parte das crianças freqüenta a escola da missão, e a maioria dos jovens fala espanhol, com diferentes graus de fluência. Também a maioria dos homens, senão todos, já visitou La Esmeralda, e muitos fazem-no regularmente. Um número considerável esteve em Puerto Ayacucho ou em outras cidades no norte do país. Muitos Yanomami também participam da política local partidária ou indígena, e outros foram treinados como enfermeiros, microscopistas e assim por diante.

\section{Quadro teórico}

Nesta seção, introduzo a linguagem teórica sobre a qual o restante de minha análise está construído. Nesse sentido, faço uma breve apresentação da teoria do parentesco ameríndio sintetizada por Eduardo Viveiros de Castro (1993), buscando, em seguida, mostrar algumas de suas afinidades com a teoria do simbolismo de Roy Wagner $(1978 ; 1981)$ — afinidades já assinaladas pelo próprio Viveiros de Castro (2001). O notável estudo de Bruce Albert (1985) sobre os Yanomami do Brasil contém, entre seus muitos méritos, uma descrição do espaço sociopolítico yanomami como um sistema dinâmico que envolve esferas internas e externas do socius, mutuamente constituídas por ciclos de morte, luto e serviços funerários. Ao mesmo tempo, Albert deixa claro que não estamos lidando com "sociedades do parentesco", sublinhando como relações supralocais de caráter político-ritual são fundamentais para a constituição do "local". Mais tarde, Viveiros de Castro (1993; 2002a) sugeriu que a distinção ternária analisada por Albert entre coresidentes, amigos/aliados e inimigos poderia ser vista, com suas inflexões específicas, como típica da região amazônica como um todo.

Esse modelo, uma verdadeira síntese do parentesco ameríndio, sublinha, mais uma vez, a subordinação do parentesco e do local aos valores associados à exterioridade - fundamentalmente, aqueles da afinidade e da predação canibal. Dessa maneira, passa-se do plano do parentesco para uma muito mais inclusiva "teoria da relacionalidade generalizada". 
Figura 1: o estado do Amazonas com a localização dos postos de saúde (mapa extraído de Toro 1997:321)

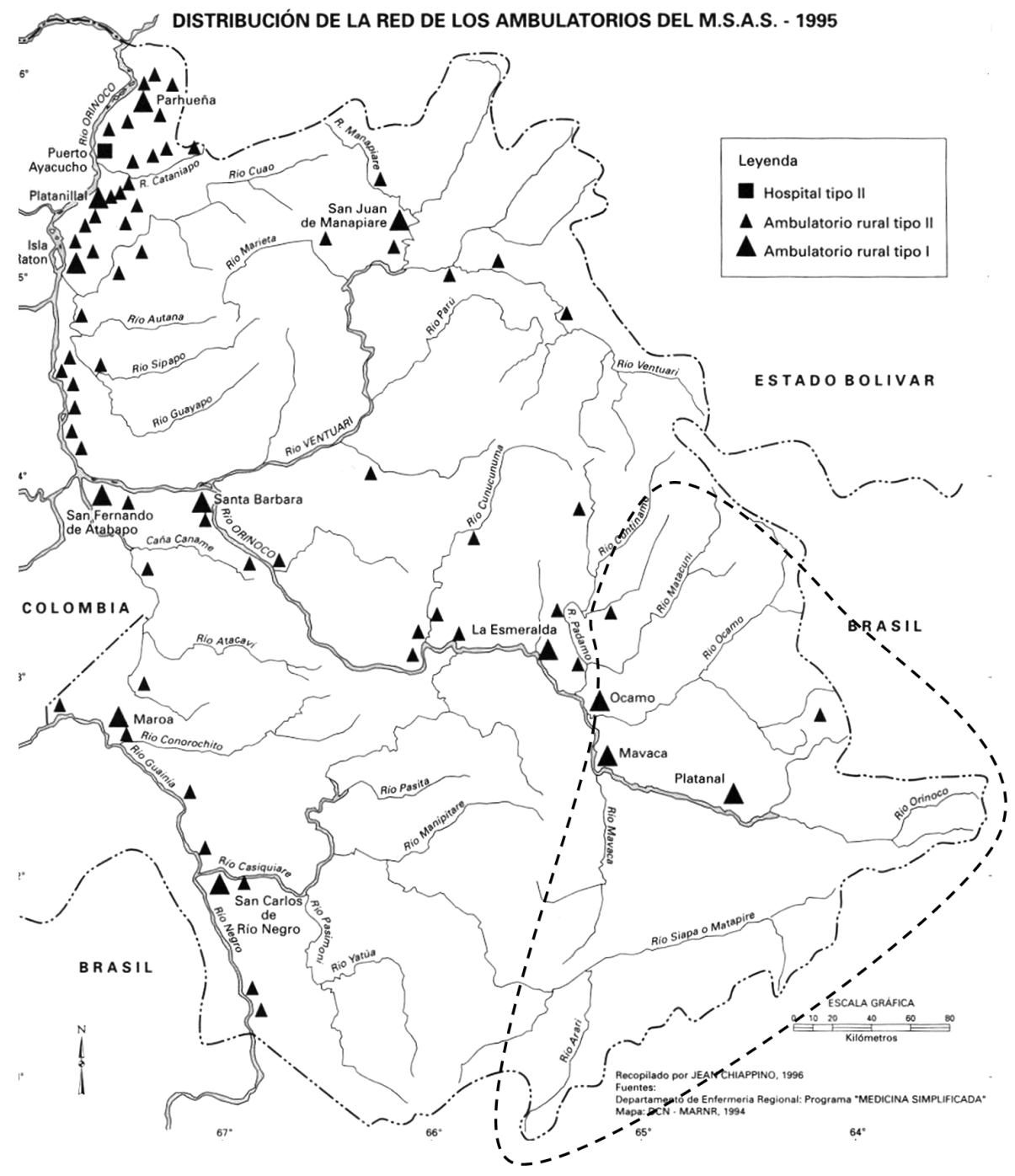


Para resumi-lo algo toscamente, o modelo sugere um jogo hierárquico entre afinidade e consangüinidade, os marcadores canônicos da alteridade e da identidade em toda a região: no nível do grupo local, em termos comportamentais, ideológicos e terminológicos, a afinidade reina sobre a consangüinidade; no nível supralocal esta hierarquia é invertida, e, no plano global, é a afinidade mesma que se vê sobredeterminada pela relação com o exterior. Esse exterior, que envolve tipicamente as categorias de "pessoas distantes" e "inimigos" — mas também de pessoas não-humanas — contém os recursos simbólicos para a reprodução social de pessoas e grupos, recursos freqüentemente capturados por meio da inimizade simbólica e da predação canibal. "Outros, perigosos mas necessários" resume tanto a necessidade social de afins quanto a necessidade político-ritual de inimigos, envolvidas em diferentes aspectos da produção de pessoas e parentes ${ }^{2}$. Essa relação ambígua com a alteridade extrema é sumarizada pela noção de "afinidade potencial" de Viveiros de Castro.

Um "afim potencial" é alguém com quem se tem uma relação na qual não há efetivação da afinidade real porque o que se troca com ele são outras coisas (rituais, mortos, nomes, almas, cabeças etc.); uma relação que é "coletiva e genérica", envolvendo troca com o exterior da esfera do sociável. A afinidade potencial "qualifica relações entre categorias genéricas: compatriotas e inimigos, vivos e mortos, humanos e animais, humanos e espíritos [...]. [Ela] é um fenômeno político-ritual, exterior e superior ao plano englobado do parentesco" (Viveiros de Castro 2002a:159).

O dinamismo deste sistema — os meios pelos quais os recursos "do exterior" são incorporados — é fornecido pela ponte representada pelos "terceiros incluídos". Trata-se, aqui, de relações ritualizadas com indivíduos da categoria dos afins potenciais que desempenham um papel de mediadores entre os grupos opostos "nós/eles"; entre o local e o exterior (Viveiros de Castro 2002a:162). Viveiros de Castro extrai muitos de seus exemplos das expressões ritualmente elaboradas da afinidade nas relações guerreiras que ligam matador e vítima. Tal é o caso entre os Tupinambá, Araweté, Wari' e Jívaro. Mas essa relação especial é também característica das amizades formais (Descola 1997, para os Achuar), dos parceiros comerciais (Overing 1983-1984, para os Piaroa), ou do papel dos afins classificatórios nos ciclos de cerimônias funerárias yanomami (Albert 1985). A noção é também aplicável a certos relacionamentos de compadrio entre índios e patrões brancos (Hugh-Jones 1992; Gow 2001).

Central para a análise de Viveiros de Castro é a noção de que a afinidade (a forma da diferença) é o estado fenomenologicamente dado da relação, e de que a consangüinidade (forma da semelhança [sameness]) deve 
ser intencionalmente criada - em suma, a diferença e o exterior são dados e o parentesco e a semelhança são produtos da agência humana. Como bem colocou Aparecida Vilaça, as pessoas fazem, de Outros, parentes (Vilaça 2002). Chamemos esse modelo "o espaço (sociopolítico) convencional ameríndio".

Um tal modelo nos aproxima da teoria do simbolismo de Roy Wagner (1981), que alimentou um importante conjunto de idéias na antropologia melanésia (em particular o trabalho de M. Strathern), idéias estas que também foram examinadas em contextos amazônicos, nos quadros de uma recente aproximação entre as antropologias amazônica e melanésia (ver Tuzin e Gregor 2001; Strathern 1999; Viveiros de Castro 1998). Wagner sugere que todas as sociedades atribuem uma parte do todo fenomenológico ao reino do inato ou do dado, e outra, necessariamente, ao que fica disponível à agência humana. A ação humana sempre envolve uma dialética, uma relação entre figura e fundo, entre esses dois reinos. É nesse contexto que se pode entender a proposição de Viveiros de Castro de que, na Amazônia,

\begin{abstract}
Uma vez que a afinidade é o estado fundamental do campo relacional, algo deve ser feito, uma certa quantidade de energia deve ser dispendida para se poderem criar zonas de valência consangüínea nesse campo. A consangüinidade deve ser deliberadamente fabricada; é preciso extraí-la do fundo virtual de afinidade, mediante uma diferenciação intencional e construída da diferença universalmente dada (Viveiros de Castro 2002a:423).
\end{abstract}

Para levar essa análise adiante, é preciso introduzir um pouco mais da linguagem wagneriana. Primeiro, a proposição de que muitos "povos tribais" subsumem o mundo da convenção - moralidade, linguagem, o leque de regras que reunimos sob a categoria "cultura" - no reino do inato ou dado. Lembremo-nos do peso que os ameríndios atribuem ao falar a língua como marca de humanidade, ou, de modo mais geral, do modo como a inclusão na categoria de "gente de verdade" depende do grau em que comportamentos morais são adotados (ver, p.ex., McCallum 2001). Podemos também recordar a origem mítica da convenção cultural e, como argumentou Viveiros de Castro com respeito ao perspectivismo, o fato de que a cultura é una e partilhada através da fronteira humanos/não-humanos, associando-se à posse de uma alma e ao estatuto de pessoa.

Contrastivamente, e em termos muito amplos, euro-americanos de classe média experimentam a cultura como produto de nossa agência histórica - enquanto realizações humanas, línguas, convenções culturais e tecnologia mudam ao longo do tempo. Aqui, a forma do inato é representada 
eminentemente pela natureza e pelo mundo do "incidente natural", que constitui o substrato sobre o qual se age. Entre essas duas tradições (ideais), a distribuição do "inato" ou "dado" e do "feito" ou "artificial" é, portanto, invertida. Retornarei adiante à significância dessa inversão.

Em segundo lugar, há a distinção entre convenção e invenção. Em qualquer sociedade, a convenção consiste no aspecto coletivizante do mundo vivido, quer dizer, aquilo no significado que permite o reconhecimento de alguma coisa como um exemplo de algo já conhecido. Todas as regras, códigos ou organização que permitem o compartilhamento de significados pertencem ao mundo da convenção. Sua contrapartida é a invenção, que subsume tudo em um significado que diferencia e particulariza. A proposição de Wagner continua, pois, a ligar o inato e o artificial ao convencional e ao inventivo.

Em tradições diferenciantes, uma vez que o coletivo está dado, o que se busca fazer é particularizar a partir de um fundo de similaridade; aqui, o que as pessoas almejam é "desestabilizar a convenção" (Wagner 1981:88), esforçando-se para diferenciar-se de outros, do mesmo modo que os poetas aspiram à originalidade. Correlativamente, Viveiros de Castro, em sua análise do parentesco ameríndio, observa como "o gradiente de distância é o terreno por excelência da performação, da interação entre norma e ação, estrutura e história [...]. [...] aqui, o 'jogo' das regras é parte das regras do jogo" (2002a:133). Esse "jogo das regras" parece convergir com a idéia de uma diferenciação constante a partir de um fundo de convenção. Na cultura euro-americana, ao contrário, produzir deliberadamente o convencional constitui uma orientação normal. A construção de regras, cronogramas e organização é vista como necessária para coletivizar as particularidades inatas das pessoas, de maneira a possibilitar a vida em sociedade.

Estamos, agora, em posição de explorar o modo como essa teoria de um espaço convencional ameríndio, em conjunção com as proposições de Wagner, pode auxiliar nossa análise das relações dos Yanomami com os brancos.

\section{O "eixo de transformação em branco": a extensão da convenção}

O espaço convencional serve, em primeiro lugar, como um modelo interpretativo para as relações com os brancos. Albert (1988) mostrou como, para os Yanomam, os brancos situaram-se historicamente em diferentes esferas sociopolíticas, sendo primeiramente tomados como fantasmas (nos contatos iniciais), em seguida como inimigos (extrativistas), e, finalmente, como amigos (principalmente os missionários). O influxo de doenças e de 
objetos manufaturados foram os fatos mais importantes do contato, que alimentaram as interpretações dos Yanomam. Na medida em que os brancos são "domesticados", aproximando-se forçosa ou voluntariamente das convenções indígenas que regem o comportamento moralmente adequado (partilha, co-residência, fala apropriada, uso de termos de parentesco etc.), vêem-se incluídos no reino da humanidade, e a distância social vê-se progressivamente reduzida. Minhas narrativas das relações históricas dos Yanomami com extrativistas brancos e missionários, ao longo do alto Orinoco, bem como os relacionamentos presentes com os médicos rurais que trabalham nos postos de saúde, confirmam as análises de Albert.

Todavia, se as trajetórias dos brancos constituem uma extensão criativa da convenção yanomami - uma incorporação do desconhecido enquanto forma do conhecido - , essa convenção vê-se, assim, necessariamente modificada e exposta à inovação. Nesse aspecto, afastamo-nos de Albert para explorar a face complementar de sua análise da antropologia indígena dos brancos: a saber, aquilo que propomos chamar um eixo de inovação.

As noções relacionalmente constituídas de yanomami e napë são transformadas na medida em que se intensificam as trocas interétnicas. Um novo contexto de interpretação das relações vai emergir. Esse "eixo de transformação em branco" coexiste com aquele descrito por Albert (1985), mas sua variável-guia não é a "inimizade", mas a "transformação histórica em branco". Esse "eixo" deve ser entendido como um contexto: um conjunto de conceitos e práticas que constitui uma rede de relações convencionais, a qual reúne ou sepa$\mathrm{ra}$, contextualmente, diferentes categorias de Yanomami e de brancos.

Talvez o campo semântico do termo yanomami napë seja o que exibe mais claramente a coexistência do "espaço convencional" e de sua inovação: o "eixo de transformação em branco". No primeiro plano, napë tem conotações de uma alteridade concebida como inimizade. Seu sentido mais simples é "diferente", "estrangeiro", "pessoa não yanomami" (Lizot 2005:249). Uma série de termos derivados associa-se a ele, como napëmai, "odiar, detestar ou ter aversão por alguém", ou napëmou, "ameaçar, demonstrar hostilidade". Mas o campo semântico de napë tem também um outro lado que se refere aos brancos: napëai, "começar a conhecer os brancos, ou a gostar deles"; napëmou, "comportar-se como branco, falar espanhol"; napëprou, "virar branco" (Lizot 2005:250). É importante notar que, em ambos os casos, napë é um conceito estritamente relacional, que se refere ao modo como uma pessoa ou grupo se coloca face a outro.

$\mathrm{O}$ fato de que os brancos sejam também chamados napë lembra-nos que a inovação é uma extensão - e não uma obliteração — da convenção: há algo de inimigo nos brancos. É preciso recordar, aqui, que os Yanomami 
atribuem aos brancos a disseminação de doenças epidêmicas classificadas como shawara (malária, sarampo, coqueluche, hepatite etc). Por um lado, eles se recordam do modo como as doenças chegaram, com as primeiras incursões dos brancos em seu território. A aproximação dos Yanomami dos grandes rios, em busca do contato com os brancos, representou uma opção histórica em que o sofrimento crescente causado pelas doenças foi o preço pago pelos múltiplos benefícios - econômicos e políticos, individuais e coletivos - da proximidade com os missionários. Por outro lado, muitos defendem a teoria segundo a qual os processos de combustão executados pelos brancos (por exemplo, nos transportes e nas fábricas, mas também na queima de pordutos manufaturados como plástico, lixo, roupa etc.) disseminam os demônios da doença (shawara).

Consideremos os termos em que as pessoas falam em "virar branco" e a concomitante emergência, nesse contexto, do que batizei de "eixo de transformação em branco".

As narrativas do povo de Ocamo sobre o passado recente e missionário falam de transformação nas relações com os brancos. Um conjunto de idéias refere-se a mudanças de habitus que corroboram a análise que Vilaça (1999) — baseando-se em uma noção perspectivista do corpo - faz do contato interétnico como "metamorfose". Outro conjunto relata a aquisição de conhecimentos dos brancos ${ }^{3}$. Ambos estabelecem um elo entre o "como costumávamos ser" e o como aqueles que vivem rio acima continuam sendo. Assim, esses contextos de transformação em branco têm uma referência tanto histórica quanto sincrônica, tanto temporal quanto espacial.

\section{Na história}

As transformações no habitus referem-se, geralmente, ao modo como, agora, as pessoas comem a comida dos brancos e vestem suas roupas; às vezes, também, à adoção de tetos de zinco e de motores, e à mudança do habitar o "fundo" da floresta para morar nas proximidades dos grandes rios, mais perto dos missionários. Outra referência importante é a disseminação de doenças epidêmicas (shawara).

A aquisição de conhecimento é formulada, principalmente, em termos da experiência com a educação formal, da habilidade em falar o espanhol e em lidar com os brancos, e da capacidade de evitar ser enganado ou explorado por eles.

Outro elemento que sustenta a idéia de transformação ou metamorfose é o uso da partícula -pro- , na expressão napëprou, que consiste na maneira 
usual de dizer "ser civilizado". Segundo Lizot, -pro- "conota a idéia de transformação e, quando sufixado a um nome [como napë], o verbaliza, indicando uma mudança de natureza, estado, forma etc." (1996:83). Mais do que isso, -pro- indica a fase final de um processo ainda em curso; o perfectivo prariyo- é usado quando o processo se completa. Assim, napëprou significa, de fato, "virando napë". Transformações míticas, como a metamorfose, são também lingüisticamente marcadas pelas formas pro/prariyo.

Estar napëprou é imaginar-se em um estado contínuo de transformação em napë. Esse sentido de napë como limite - um ponto do qual você se aproxima, mas nunca atinge - é consistente com o discurso político dos representantes yanomami, que retratam os atuais Yanomami como "percorrendo o caminho do napë" (isto é, "progresso").

O seguinte comentário de um influente homem de Ocamo permite dar uma idéia de como algumas dessas noções emergem na conversação. Ele se refere, aqui, aos missionários locais, que hoje relutam em ser tão generosos quanto foram no passado.

Sempre digo, "antes, quando ele [missionário] nos ensinava, quando ele estava nos ensinando, antes ele dava presentes... Ele trazia todo tipo de coisa, panelas, panos, anzóis, linha; ele ajudava, cozinhava trigo... ele dava comida, ralava mandioca..." Então eles [os velhos] pensam ainda: "porque eles [os missionários de hoje] não fazem como aquele missionário"? Eu digo, "não, ele primeiro nos ensinou, ele nos ajudou porque nós não sabíamos a língua do napë, nós éramos realmente yanomami, realmente waikasi, ele nos ajudava. Agora não há mais ajuda, agora nós sabemos como falar, sabemos como estudar e precisamos agora pensar como vamos conseguir dinheiro com trabalho... Não é como costumava ser".

Temos aqui duas idéias que remetem à nossa "teoria tradicional" e podem ser incorporadas à análise do "virar branco".

Em primeiro lugar, como resultado dessa transformação histórica, da qual meus interlocutores tendem a falar com orgulho (ver Gow 2001), os Yanomami de Ocamo podem referir-se a si mesmos como "Yanomami civilizados": "nosotros ya somos civilizados". É importante notar que o ser civilizado não substitui o ser yanomami - as pessoas não negam sua yanomami-dade. Uma representação mais adequada dos Yanomami de Ocamo os descreveria em termos de uma dualidade yanomami/napë. Aqui, deparamonos com uma importante continuidade em relação às diferentes expressões da constituição Eu/Outro da pessoa - como fusão reflexiva de diferentes perspectivas - descrita, com diversas inflexões, como característica das 
noções ameríndias de personitude [personhood] (Viveiros de Castro 2001; Kelly 2001). Sugiro pensar essa dualidade como equivalente àquela implicada no fato de uma pessoa ser um consangüíneo para/de alguns e um afim para/de outros; àquela implicada em ter-se um corpo fabricado sob o modo da consangüinidade e uma alma dada sob o modo da afinidade (Viveiros de Castro 2001:33). Aqui, as pessoas são yanomami para/de alguns e napë para/de outros; a passagem de uma coisa para a outra consistindo em uma mudança de ponto de vista (da perspectiva dos que vivem à jusante, para àquela dos que vivem à montante, respectivamente).

Em segundo lugar, para os "Yanomami civilizados", nenhuma dessas transformações parece afigurar-se como reversível. Por um lado, a floresta encontra-se "infestada" por doenças; por outro, ninguém aparenta desejar retornar para o fundo da floresta e abandonar seus pertences de branco. Em alguns contextos, fala-se dessas transformações em termos similares aos aplicados às transformações míticas. Aqui, defrontamo-nos com uma segunda continuidade com relação aos aspectos tematizados pela "teoria tradicional" (pois, como sugeriu Gow sobre os Piro, em certos contextos, essas transformações seriam concebidas como repetição ou exemplo de transformações experimentadas pelos "antigos" em tempos míticos). E, da mesma maneira que os animais não podem se des-transformar em Yanomami antigos, os Yanomami civilizados também não podem voltar atrás em sua trajetória de devir. Existe, além disso, uma ressonância entre o processo de "virar branco" e outras formas de "devir-Outro".

O eixo de transformação em branco exibe essa continuidade com a forma ameríndia de "habitar o tempo" (Gow 2001). Muitos etnólogos já observaram que os mundos vividos indígenas apontam mais para um constante "devir" que para um "ser" estável. Por exemplo, "[p]ara os Araweté, a pessoa está, intrinsecamente, em transição; o destino humano é um processo de 'devir-Outro'" (Viveiros de Castro 1992:1). Para os Araweté, o que está em jogo é virar um maï, deuses que ocupam a posição ambígua de destino post mortem e inimigos canibais. Para os Tupinambá quinhentistas, o que estava em jogo era o "devir-inimigo" (Viveiros de Castro 1992:1). A análise de Gow das relações históricas dos Piro com os brancos mostra que o mundo vivido piro é um "sistema de transformações", em que mito e mundo vivido ecoam, cada um, a natureza intrinsecamente transformacional do outro.

As mudanças $[\ldots]$ nos estilos de vestimenta, no xamanismo ou na vida ritual ao longo do século XX são mudanças genuínas, e devem ser entendidas enquanto tais pelo analista. Elas são assim entendidas pelos Piro. Mas elas não colocam para eles o problema da continuidade e mudança, pois os Piro sabem que elas 
são transformações de transformações. Por exemplo, a "roupa dos antigos" e a "roupa dos brancos" são certamente diferentes, mas são versões transformacionais da mesma transformação que toda roupa realiza (Gow 2001:309).

Parece-me que napëprou é a forma principal de diferenciação, contra um fundo de similaridade yanomami, que os Yanomami de Ocamo têm à sua disposição. Na linguagem de Wagner, "devir-Outro" é diferenciação, e quando o nome do jogo é diferenciação, a transformação é aquilo que "acontece" ao longo do tempo.

Essa intuição deve nos acautelar contra a descrição dos processos históricos indígenas em termos de rupturas radicais de equilíbrio ou mudanças drásticas no interior de culturas duradouras. O que constitui uma "ruptura radical" quando a transformação é constante? Contra que fundo de continuidade desenrola-se a "mudança"? Não se trata de negar a experiência indígena de mudança cultural e social, mas de questionar, de uma perspectiva indígena, a natureza e os valores associados com a "mudança". Seguindo as observações de Wagner (1981) e Viveiros de Castro (2002b) sobre a natureza da investigação antropológica — sobre a necessidade de identificar as perguntas de nossos interlocutores nativos, em lugar de buscar respostas para as nossas próprias - o estudo da história indígena não deveria limitar-se a propor aos índios nossas interrogações, na esperança de obter deles uma "etnohistória". Devemos ir buscar o análogo de nossas inquietações com a mudança histórica entre os indígenas - o que poderia nos levar a preocupações quanto à maneira de efetuar transformações e diferenciação (cf. Strathern 1990).

\section{Ao longo do rio}

O aspecto sincrônico do devir consiste na projeção da transformação histórica em uma rede geográfica que forma o substrato para as práticas e significados que constituem o "eixo de transformação em branco". Se "virar branco" produz pessoas duais yanomami/napë enquanto fusão de perspectivas distintas, essas perspectivas devem ter um locus em uma rede de relações. Aqui, sigo a análise de Peter Gow (1993; 1994) da imageria de "gringos" e "índios selvagens" dos Piro. Os Yanomami de Ocamo movem-se rio acima e rio abaixo e, dessa maneira, trocam bens, experiências e idéias com outros índios e brancos a jusante, e, a montante, com outros Yanomami, menos familiarizados que eles com o mundo dos brancos em termos de educação, saúde, política e acesso a bens. 
Os Yanomami de Ocamo enviam, rio acima, produtos manufaturados (instrumentos de metal, tecido, mosquiteiros) e recebem de lá produtos indígenas (alucinógenos, tabaco, bananas-da-terra). Deslocamentos ao longo do Ocamo para cerimônias funerárias reahu e outras visitas são freqüentes; além disso, tipos completamente novos de relação estão também emergindo. Os Yanomami de Ocamo acompanham os médicos que sobem o rio como auxiliares, intérpretes e enfermeiros; políticos de Ocamo aventuram-se à montante, a fim de conquistar apoio para si ou para seus partidos e, por último, alguns Yanomami influentes contratam pessoas de lá para a derrubada de suas roças ou a limpeza do terreno em torno de suas casas. Os moradores de Ocamo abrigam, ocasionalmente, filhos de parentes seus que vêm estudar na escola. Quando os Yanomami de rio acima precisam tratar-se na clínica rural e hospedam-se com parentes seus, outros zombam de sua desorientação e ignorância quanto ao estilo de vida em Ocamo. Todas essas relações desenrolam-se em um contexto de "transformação em branco" e envolvem duas posições: napë, marcada pelo habitus e conhecimentos dos brancos, e yanomami.

Nesse "eixo de transformação em napë", os moradores de Ocamo consideram-se yanomami e a categoria napë refere-se aos missionários, aos médicos, aos antropólogos e a todos os não-indígenas que vivem além do Alto Orinoco. É apenas em referência a si mesmos - Yanomami - que consideram os Yekuana, seus vizinhos, também napë. Historicamente, todavia, antes do encontro com os brancos e de sua transformação, os Yekuana eram também, com base no habitus, yanomami. Quando os não-indígenas são tomados como referência, todos os índios são yanomami. Apenas em um contexto mítico os brancos podem ser considerados yanomami, na medida em que também eles são o resultado de transformações dos antigos; afora este, não há outros contextos em que os brancos possam ser vistos como yanomami e, nesse sentido, eles são napë yai, "napë de verdade"4. O termo yai (em espanhol, propio) carrega as conotações de "real", "essencial", "verdadeiro"5.

Ser yanomami é algo que o povo de Ocamo compartilha com os que vivem rio acima, mas há também o reconhecimento de que estes últimos são "yanomami de verdade", do mesmo modo que, em comparação com os Yekuana, os brancos são napë yai, "brancos de verdade". Waikasi é um termo que expressa esse sentido de "yanomami de verdade", conotando a condição de "não-civilizado", de "ser como os antigos", associada aos Yanomami da montante do rio. Esse uso deriva do termo que os brancos empregavam para designar os Yanomami, com conotações de "selvagem assustador". Todavia, waika é uma palavra yanomami para designar Outros, formando um par contrastivo sociológico e geográfico com shamathari: do ponto de vista 
de qualquer grupo dado, os waika são Yanomami que estão ao norte e os shamathari encontram-se ao sul (Lizot 1994:227).

\section{Um exemplo: Yanomami e napë no contexto da troca}

Talvez o contexto da troca de bens seja aquele que mais claramente exemplifica as novas conotações de yanomami e napë. Da perspectiva dos que vivem nas partes média e alta do rio, os Yanomami de Ocamo são, em certos contextos, considerados napë. Um traço destaca-se como definidor do grau de napë-idade: posse ou provisão de bens manufaturados. Em uma comunidade à montante de Ocamo, indaguei se as pessoas rio abaixo, na missão em Ocamo, eram napë ou yanomami.

O pessoal de Ocamo? Os que vivem na missão? Não, eles não são napë... Em La Esmeralda as pessoas são napë; em Ayacucho são napë, mas no Ocamo não são napë. Se fossem, eles iam trazer muita ajuda [material] para nós aqui.

Essa afirmação retrata belamente o gradiente espacial da napë-idade. Esse homem, que visita Ocamo com freqüência e vê a si próprio como estando mais ou menos em pé de igualdade com eles quanto à sua napëidade, nos informa qual é a marca do "napë de verdade": além da posse de bens, a capacidade de provê-los. Um homem influente em Ocamo, referindo-se a um líder que sempre diz "ser igual aos napë", desenvolve mais o tema:

[...] "Se você quer ser napë, tudo bem, mas então, o que você vai me dar, se você está virando napë? Nada!", isso é o que os Yanomami dizem... "Ok, você quer ser napë mas onde você vai fabricar [em espanhol] anzóis, linha, machetes?" É assim que eles falam.

Aqui, napë, além de provisão, é também produção. Para resumir, o gradiente de napë-idade vai da posse à provisão e desta à produção de objetos manufaturados, e, nesse contexto de troca, qualquer um que tenha objetos para dar ocupa uma "posição napë" perante àquele que recebe tais itens ou carece deles — que estará em uma "posição yanomami". Os pólos são napë yai (produtores) e waikasi (sempre receptores). Todos os que se encontram no meio (o pessoal de Ocamo e do curso médio do rio) são, em sua condição de intermediários, yanomami/napë. Vistos da perspectiva de rio abaixo, são yanomami (receptores); da de rio acima, são napë (provedores). 


\section{"Brancos de verdade"}

Assim como existem marcadores da condição de "yanomami de verdade", existem associações vinculadas àquela de "napë de verdade". A condição de napë yai expressa-se mais perfeitamente em poderosos homens brancos que vivem além do Alto Orinoco e que podem influenciar significativamente a vida dos Yanomami: gente como o presidente; algumas organizações de ajuda humanitária; ministros; o governador; funcionários superiores de instituições com as quais eles têm contato local (como o Diretor de Saúde Regional) etc. Essas personalidades podem mobilizar importantes quantidades de produto manufaturado, promover cursos para enfermeiro ou microscopista, obter quantidades maciças de gasolina ou de comida para reuniões, mobilizar helicópteros em caso de epidemias, influenciar na demarcação de terras etc. Elas representam fontes poderosas que propiciam ao pessoal de Ocamo as condições para "virar napë". Mas esta é uma das muitas expressões do poder e perigo dos brancos. Napë é também associado a um conhecimento extraordinário, evidenciado na tecnologia que médicos e missionários trazem ao Alto Orinoco. O hospital em Puerto Ayacucho pode ser visto, por um lado, como um lugar de alta tecnologia e grande conhecimento das doenças (aparatos e médicos especialistas), mas algumas viagens até lá terminam em morte - de maneira que o hospital também pode, por outro lado, aparecer como um lugar perigoso, cheio de napë nada confiáveis. Existe também a noção de que episódios de epidemias resistentes originam-se em terras mestiças identificáveis, como o Brasil, por exemplo. Por fim, a figura do malandro, caracteristicamente um residente da cidade de Puerto Ayacucho, ocupa um lugar especial no imaginário de Ocamo. Malandro é uma categoria que inclui de ladrõezinhos a assassinos, e parece que ninguém escapa de ter tido ao menos um encontro com um napë desse tipo, violento e irresponsável.

Resumindo: os brancos tornaram-se forasteiros arquetípicos, uma síntese de significados referentes a uma mistura de poderes criativos e destrutivos. Do mesmo modo que, na Amazônia, um inimigo é freqüentemente um parceiro de troca, um nominador, um fertilizador; o napë yai epitomiza a natureza ambígua dos brancos: possuidores e criadores de bens manufaturados, criadores e disseminadores de doenças, algumas vezes, malandros periogosamente violentos; outras vezes portadores de ajuda aos Yanomami (missionários, médicos). Deste conjunto de napë yai saem todos os brancos locais/residentes (missionários, médicos, militares), que são vistos como menos poderosos e "virulentos", logo que com eles se estabelece alguma familiaridade. Brancos residentes são versões "domesticadas" do produto original. 
Figura 2: 0 eixo transformacional napë: da perspectiva de Ocamo6

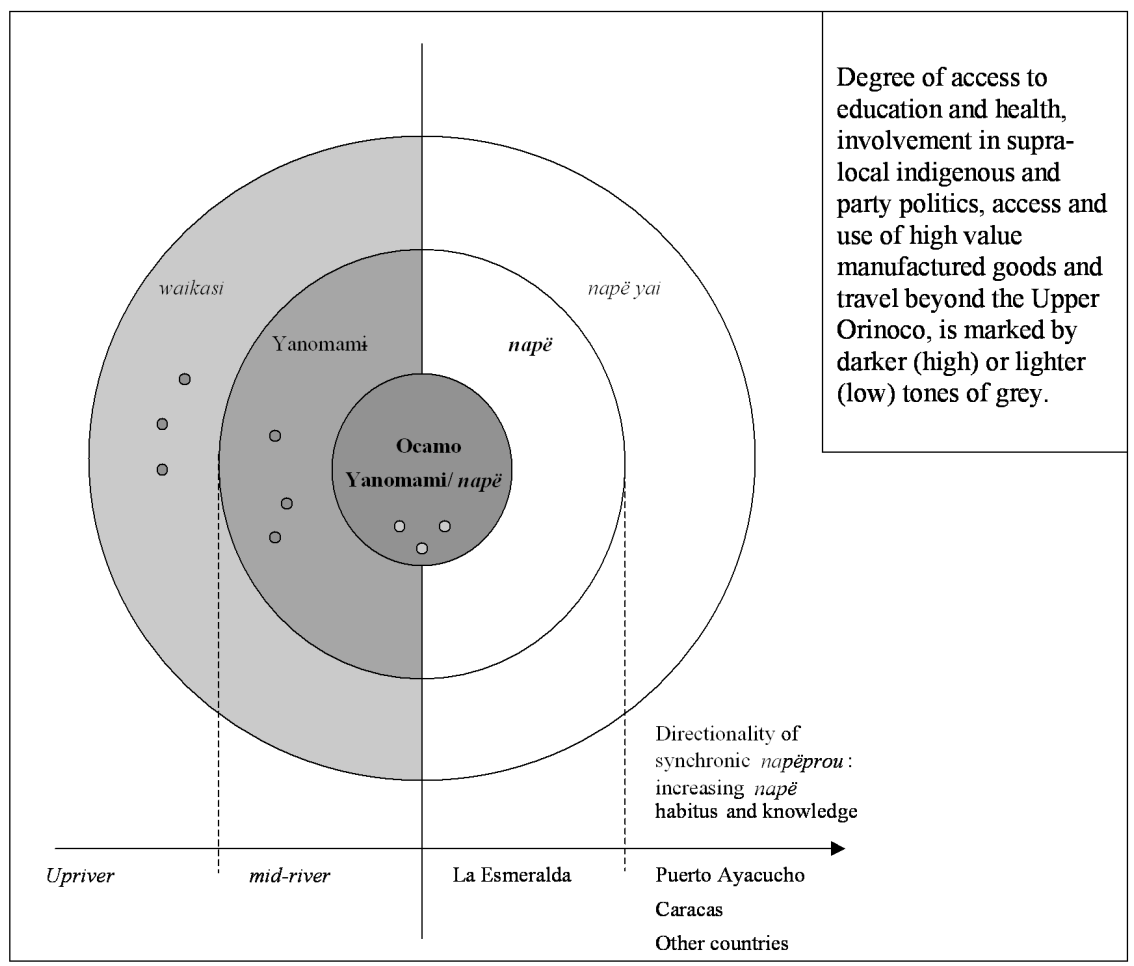

Façamos agora uma segunda pausa, pois quero sugerir que o eixo de transformação em branco retém a composição ternária do espaço convencional yanomami. A esfera dos "brancos de verdade", napë yai, é uma expressão do "poder do exterior", essencial para a reprodução social, um tema característico do espaço convencional ameríndio. Meu argumento coincide com os de McCallum (2001) e Gow (2001), no sentido de propor ser essa esfera a fonte que torna possível uma vida "yanomami/napë". Os "brancos de verdade" conservam, desse modo, - enquanto "Outros perigosos, mas necessários" — o status ambíguo de afins potenciais, e podem ser, portanto, apropriadamente caracterizados como tal, como o faz Gow (2001). Mais do que isso: brancos residentes - como missionários e médicos — que foram "domesticados" podem, enquanto versões enfraquecidas de napë yai, ser pensados como "terceiros incluídos", que servem como pontes para a captura de benefícios do exterior. Finalmente, o lugar dos 
parentes reais (consangüíneos e afins) no espaço convencional corresponde, no eixo de transformação em branco, ao dos próprios Yanomami, visto que, na maior parte dos contextos (por exemplo, reuniões políticas), yanomami, como posição em uma relação, constitui um par contrastivo com napë.

Isso é congruente com nossa proposição de que a relação com o exterior é parte do componente inato do mundo vivido indígena. A agência humana pode seja domesticar forasteiros, seja mantê-los à distância. A domesticação envolve um movimento da alteridade para a identidade: pessoas individuais podem percorrer esse caminho, como os primeiros missionários ou os médicos de hoje, mas a natureza do exterior permanece não afetada por essa passagem individual. Mais uma vez, isso nos convida a pensar não tanto em termos de mudança histórica, mas sobre o que permanece constante à medida em que a história se desdobra: a saber, certas formas por intermédio das quais realiza-se a necessária diferenciação local na produção de pessoas, ao mesmo tempo em que o exterior é mantido como fonte de recursos diferenciantes.

\section{Domesticando brancos e virando branco}

Vejamos como uma "teoria da relacionalidade generalizada" pode iluminar a relação entre os processos simultâneos de "virar branco" e de "domesticar os brancos". Isso parece especialmente oportuno na medida em que tratam-se de dois processos mutuamente implicados: a redução da alteridade dos brancos e a produção da alteridade interna. Mas qual a relação entre essas duas transformações?

Uma convergência importante é que ambos falam de diferenciação, mas, e isso é crucial, um "acontece" no contexto do "espaço convencional Yanomami", enquanto o outro "acontece" no contexto de "transformação em napë".

Napëprou - virar branco - consiste em uma transformação de corpo/habitus e uma aquisição de conhecimentos que é intencionalmente produzida ou "trabalhada" sobre a base da condição inata de yanomami. É por isso que a condição dual de yanomami/napë é referida como "virar napë": ser yanomami é um estado não-marcado. Ser yanomami, como uma condição moral/humana/inata, 'coletiviza' (identifica) os Yanomami "civilizados" de Ocamo com seus compatriotas rio acima, e diferencia coletivamente todos os Yanomami dos brancos. O "lado" napë dos Yanomami "civilizados" é "artificial", e constitui o sítio de uma contínua diferenciação com respeito aos Yanomami à montante; 'coletiviza', assim, os Yanomami "civilizados" com os brancos, cada um em seu contexto. 
Figura 3. Sumário das relações em napëprou e "domesticando criollos"

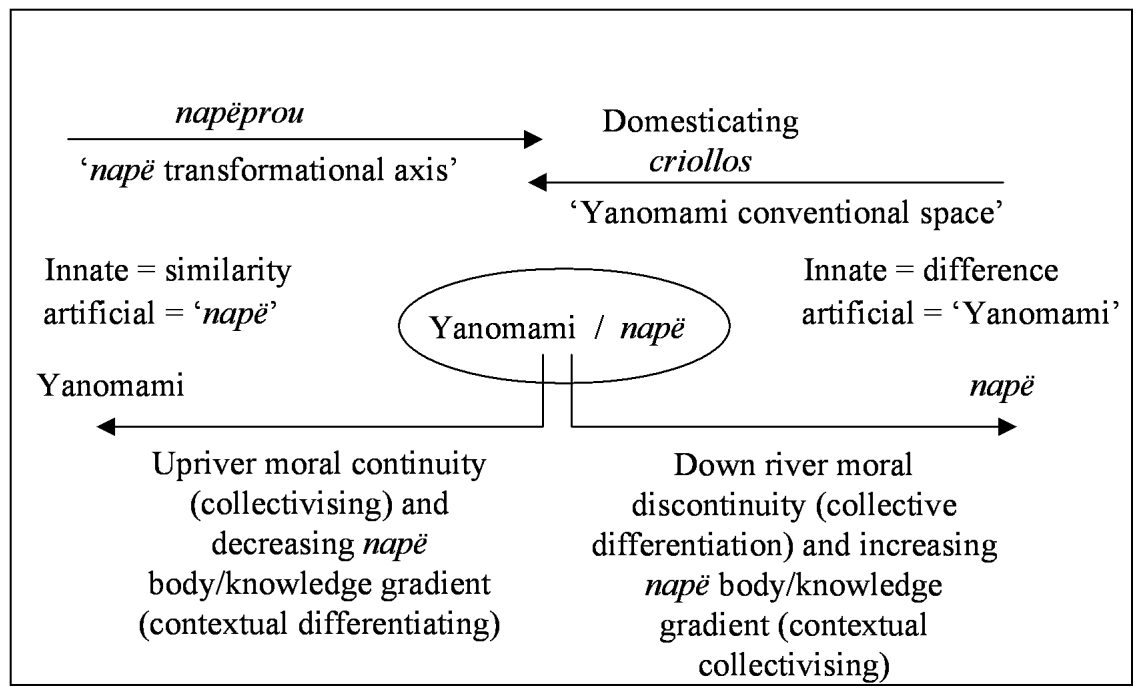

"Domesticar os brancos" remeteria mais à "teoria da relacionalidade generalizada" convencional. Trata-se de remover artificialmente a alteridade inata, comportando-se como parente e tornando-se mais humano e moral: um "virar yanomami". Na medida em que os brancos adquirem uma dualidade yanomami/napë, é sua yanomami-idade artificial (falar a língua, por exemplo) que pode 'coletivizá-los' com os Yanomami. Sua face napë inata, todavia, - seu status não marcado - diferencia os brancos, na maior parte dos contextos, de todos os Yanomami.

Esses dois processos constituem trajetórias inversas que geram um espectro performativo ao longo da rede fluvial que se estende até a cidade, no qual as pessoas diferenciam-se contextualmente e coletivizam-se em relações de troca, visitas médicas, reuniões etc.

O "eixo de transformação em napë", entretanto, difere do "espaço convencional yanomami" de um outro modo crítico: a desigualdade inerente às relações Yanomami/napë. O espaço sociopolítico ameríndio é sociocêntrico e isomórfico. Inimizade e aliança constituem relações recíprocas entre iguais. Este não é o caso das relações que sustentam as posições Yanomami/napë. Em contextos de troca, os Yanomami de Ocamo têm uma posição superior no que se refere ao controle do fluxo de bens escassos e valorizados à montante. Em termos mais gerais - porque a direção e o pólo limite no eixo de 
"transformação em branco" é a posição de napë — , isso introduz um elemento hierárquico linear na "forma clássica" do dualismo diametral e concêntrico, dissolvendo seu isomorfismo.

Ecoando parcialmente o que diz Turner (1991:297)7 sobre as relações dos Kayapó com o Estado brasileiro, o contexto de transformação em napë permanece sociocêntrico. Todavia, os Yanomami "civilizados" de Ocamo constituem mais um ponto médio em uma rede linear, do que o centro de um espaço concêntrico (donde minha preferência pelo termo "eixo", em lugar de "espaço", para falar do contexto de "transformação em napë")8.

Para permanecer nos quadros da teoria wagneriana, o que efetua tanto o "virar napë" quanto o "domesticar os brancos" é a "obviação" (Wagner 1978; 1981; 1986). Meu uso do termo é inspirado pela explicação de Wagner (1978:31-32) sobre os dois sentidos da palavra "obviar": tornar proeminente certas associações de um símbolo - torná-las imediatamente aparentes às custas de outras que, por implicação, passam assim "despercebidas".

Em referência à "domesticação dos brancos", obviar é enfatizar — artificial/intencionalmente - a semelhança, por meio da co-residência cotidiana, do uso da língua, do emprego de termos de parentesco etc.; em certos contextos ritualizados, é "ignorar" o perigo e a Alteridade inata dos brancos. Em referência ao "virar napë", a obviação ocorre quando os Yanomami enfatizam sua napë-idade às expensas da condição inata de yanomami - no contexto da interação com seus congêneres rio acima, ou quando eles enfatizam sua yanomami-dade às expensas de seu "lado napë", nas relações com os brancos. Claro está que os Yanomami "civilizados" também podem enfatizar a semelhança yanomami quando estão entre seus congêneres rio acima, ou a semelhança mestiça quando estão entre os brancos.

A obviação intencional é necessária para a sustentação do eixo de transformação em branco; isto é, é na diferenciação em relação aos "Yanomami de verdade", rio acima, em alguns contextos, e em relação aos "brancos de verdade" rio abaixo, em outros, que os Yanomami de Ocamo constroem seu ser dual yanomami/napë.

Apresento agora dois exemplos de ação diferenciante que são centrais na operação do sistema de saúde.

\section{Diferenciação à montante: uma "performance napë"}

Idealmente, os médicos visitam quinzenalmente as comunidades situadas algumas horas rio acima, e mensalmente as aldeias mais distantes. Eles planejam suas viagens com base em considerações médicas, procurando 
cumprir cronogramas de visitas ou de programas de controle (por exemplo, da oncocercose), ou respondendo a notícias específicas de adoecimento. As equipes yanomami vêem nessas viagens mais do que uma simples visita médica: para o motorista e seu(s) ajudante(s), trata-se, sempre, de uma oportunidade para visitar parentes; trocar, espalhar e coletar notícias; negociar alianças políticas ou matrimoniais e caçar.

Durante as visitas, as equipes esforçam-se bastante para marcar sua posição de napë frente às comunidades visitadas. Invariavelmente, estão completamente vestidos: calças, camisas, sapatos; algumas vezes, até mesmo capas e óculos escuros. Muitos também fumam cigarros, um hábito distintivamente napë — os Yanomami usam fumo de rolo. Seu equipamento padrão é composto por espingardas, lanternas e baterias: escassas e objeto de desejo em muitas das comunidades rio acima. A equipe também costuma fazer suas refeições junto com os médicos, um ato que não apenas significa que eles "sabem como comer a comida dos brancos", mas que também expressa, por meio da partilha alimentar, mutualidade entre eles e os brancos e sua assimilação a estes últimos. Muitas vezes, também trocam ou doam produtos manufaturados — de boa ou má vontade - o que os coloca na posição napë de "provedores de objetos".

Existe também um elemento de subordinação em uma típica cadeia de comando: uma cadeia de napë-idade decrescente. Os médicos dão instruções ao motorista, que será o "ajudante principal", e que passará aos demais tarefas como lavar louça, buscar lenha, carregar coisas. Se novos ajudantes forem recrutados no meio do caminho, ao longo da viagem rio acima, serão incorporados na extremidade inferior da "cadeia de comando", mas ainda poderão dar instruções a uma criança ou jovem para a realização de uma tarefa a eles delegada.

Todos esses são traços napë, os quais, somados à habilidade dos membros da equipe em pilotar os barcos a motor e em falar espanhol, constituem importantes marcas de diferenciação. Desta maneira, as equipes de Ocamo deliberadamente realizam uma "performance napë", exibindo um corpo/habitus e conhecimentos caracteristicamente napë (cf. Lizot 1998:30-31). Falo em performance não no sentido de uma teatralidade estratégica, mas em um sentido mais stratherniano: uma ação intencional que visa fazer com que as pessoas respondam em um sentido determinado - visando produzir uma resposta que constitua tanto evidência da efetividade daquele que age, quanto uma forma de auto-conhecimento.

Entretanto, mesmo com tudo o que fazem para diferenciar-se face a seus congêneres rio acima - que "vivem como os antigos" — os Yanomami de Ocamo mantêm seu ser dual yanomami/napë. Uma continuidade moral/ 
yanomami é estabelecida quando eles atuam como mediadores entre os médicos e a comunidade anfitriã ou quando dão objetos aos moradores destas últimas. Em ambos os casos, os Yanomami de Ocamo são compelidos por seus anfitriões a agir moralmente. Como é amplamente reconhecido, a generosidade é, possivelmente, um dos mais difundidos imperativos morais na Amazônia. Também ocorre que alguns ajudantes costumam encontrar parentes rio acima, situação na qual torna-se muito difícil recusar qualquer pedido. Enfim, todos esses atos são explicitamente morais, na medida em que diminuem o sofrimento das pessoas. Como notou Alès (2000), muitas ações são descritas pelos Yanomami como "não deixar parentes sofrerem" por meio da provisão de bens, tabaco, companhia, cura etc. Um dos exemplos mais usuais de "bom comportamento dos médicos" em Ocamo é quando estes demonstram preocupação com o sofrimento de seus pacientes. Uma das expressões mais comuns empregadas quando se quer requisitar bens ou alimento dos médicos é "estar sofrendo" (em espanhol, sufriendo).

Mas toda ação envolve tanto um aspecto convencional quanto um inventivo. O que quero sublinhar é o modo como essas performances combinam aspectos dos contextos "convencionais" e do contexto de "transformação em branco". Yanomami tem o significado de "humano/moral" assim como o de "desprovido de corpo/conhecimento [próprio] dos brancos". Napë tem o significado de "inimigo/menos moral", assim como o de "provedor de objetos/conhecimento". Nos cruzamentos desses significados, todas as performances combinam um aspecto yanomami - como continuidade moral 'coletivizante' - e um aspecto napë — como conhecimento e corpo diferenciantes. Conseqüentemente, a troca de bens manufaturados tem sempre dois lados: dar objetos é tanto moral quanto diferenciante, diminui o sofrimento e faz da pessoa, napë.

Enfim, brancos, como médicos ou missionários residentes, são inatamente napë, a despeito de sua reação aos pedidos de bens manufaturados. Se resistem a essas solicitações, são acusados de avareza, o que aponta para o significado convencional de napë (inimizade). Se as solicitações são satisfeitas, os brancos são confirmados como napë, no sentido do contexto da "transformação em branco" (provedor de objetos).

\section{Diferenciação à jusante: uma 'performance Yanomami'}

Em Ocamo, a situação equivalente à descrita na seção anterior é a dos Yanomami "civilizados" realizando uma "performance yanomami" quando querem extrair objetos dos médicos. Isso demanda a obviação da napë-idade: o apresentar-se a si próprio como um yanomami necessitado. É preciso observar 
uma importante afinidade entre a ética yanomami de "não deixar as pessoas sofrerem" - que muitas vezes obriga à provisão de bens - e o "ponto de vista napë", marcadamente definido, tanto pelos Yanomami quanto pelos brancos, pela posse de objetos, que também compele os napë e yanomami "civilizados" a oferecer bens manufaturados àqueles vistos como despossuídos.

Vejamos um último exemplo de ação diferenciante, do "performar Yanomami", mas deixando para trás, agora, o contexto de troca privilegiado ao longo de todo esse artigo.

Em abril de 2001, um grupo de Yanomami realizou um protesto por ocasião da segunda visita presidencial a La Esmeralda. Juntamente com um certo número de barcos e motores, havia lá seis "ambulâncias fluviais" para doação. Cada uma delas portava, escrito em suas laterais, o nome de uma comunidade específica; em três, lia-se "Ocamo", "Mavaca" e "Pantanal" (as demais eram destinadas a outras comunidades indígenas no médio Orinoco). Já há algum tempo, as autoridades locais de saúde vinham insistindo na inadequação técnica dessas ambulâncias: inapropriadas para viagens fluviais, medicamente mal-equipadas, com motores muito grandes para as águas rasas da estação seca, com alto consumo de combustível etc. Mesmo assim, foram levadas a La Esmeralda para serem entregues aos índios. Todavia, em um reconhecimento tardio de sua inadequação, decidiuse, no dia anterior ao evento, e depois de as ambulâncias terem sido vistas por multidões de Yanomami, substituir os nomes daquelas comunidades pelos de outras localidades no Amazonas. Essa súbita mudança, feita sem consulta aos Yanomami, motivou seu protesto.

Farei um resumo dos acontecimentos. No dia anterior à chegada do presidente, um grande número de Yanomami, sob a coordenação de suas lideranças, preparou um documento queixando-se pelo incidente das ambulâncias. A maior parte dos Yanomami estava em um acampamento provisório, reunida sob um mesmo grande teto. No dia do protesto, a maioria deles permaneceu neste lugar, enquanto o restante da população de La Esmeralda concentrava-se no fim da pista de pouso (cerca de meia milha adiante), onde tinham lugar as atividades de recepção oficiais e o programa de rádio semanal do presidente. Os Yanomami permaneceram deliberadamente afastados, com a intenção de se distinguirem dos demais. No abrigo, prepararam-se para causar impacto, reunindo flechas, improvisando bordunas e pintando-se de preto, com carvão. Um punhado deles - aqueles que desempenhavam funções de coordenação - permaneceu vestido ao modo criollo, mas os demais se apresentavam como guerreiros. Um outro grupo reuniu-se à multidão, inteiramente vestido, mantendo entretanto os guerreiros como um grupo distinguível. 
Em seguida, desfilaram ao longo da rua que levava ao palco onde o presidente discursava para a multidão. Não muito longe deste palco, os Yanomami - pintados de preto, cantando, carregando suas flechas - foram interceptados por militares. Na medida em que outros militares, alguns jornalistas, e outras pessoas chegavam ao local, o protesto acalmou-se e os primeiros, juntamente com o chefe do Distrito Sanitário, começaram a negociar com os líderes yanomami. O chefe do Distrito Sanitário tentou explicar as razões para a mudança, mas foi vigorosamente rejeitado pela multidão: "não deixem ele falar!", "livrem-se dele!". Em seguida, oficiais uniformizados tentaram esclarecer os problemas, alegando que outros barcos, mais adequados, seriam comprados. Um dos líderes yanomami veio explicar: "nós pedimos [as ambulâncias], nós estamos sofrendo aqui por nosso povo... não podemos aceitar mais enganações... agora a região yanomami está em necessidade, primeiro vocês devem se preocupar". Repetindo os argumentos anteriores, um oficial interveio - "agora eu vou explicar porque...". Em seguida, um enfermeiro Yanomami tomou a palavra: "senhores, parem com isso. Nós trabalhamos, nós morremos aqui para apresentar nossas necessidades, nós nos matamos [trabalhando pela saúde]...".

Então, um velho de Ocamo adiantou-se e, sacudindo um machado diante dos oficiais, deixou claro - em alto e bom yanomami - que ele era um verdadeiro líder. Suas palavras foram traduzidas: "ele está dizendo 'eu sou o que está sofrendo ... [inaudível] para pedir as ambulâncias e os barcos para onde o problema de saúde é maior"'9. Por fim, em voz clara, um oficial declarou: "vocês querem as ambulâncias... Bem, ok, vou dá-las a vocês. Mas lembrem-se: vocês serão responsáveis pela manutenção e operação, ok?". A multidão respondeu aplaudindo em excitação vitoriosa. Em seguida, dois documentos foram lidos em voz alta e os líderes solicitaram aos oficiais que assinassem suas declarações, com cópias para o presidente. Todo o episódio durou cerca de vinte minutos.

Vejamos a relação entre este evento e a presente discussão. Não se misturar com os demais e adotar uma aparência distintivamente guerreira consistiu, ali, um ato de diferenciação deliberado, visando uma "performance yanomami" efetiva. Afirmações do tipo "nós estamos sofrendo", "estamos morrendo", "estamos em necessidade", estão em ressonância com a ética Yanomami de não permitir que as pessoas sofram — donde a reiteração, "vocês deveriam se preocupar" - mas também ressoam com a imagem que os brancos têm dos índios como "pobres", "necessitados", "desamparados", da qual os líderes Yanomami têm plena consciência. A indumentária guerreira e o discurso assertivo ("falar sem medo") tinham o objetivo de causar medo (em Yanomami, 'kirimai). Todas essas características enfatizavam a yanomami-dade 
em detrimento da napë-idade (uma obviação), pressionando - por meio de uma combinação de medo (provocado pela aparência guerreira e pela forma assertiva do discurso) e de compaixão/piedade (provocadas pelo conteúdo do discurso) — os brancos a responder.

No contexto do "virar branco" (napëprou), essa "performance yanomami" é o complemento inverso da "performance napë" dos Yanomami "civilizados", no contexto das visitas médicas a seus congêneres rio acima. Os porta-vozes do protesto operaram a mediação entre um grupo de Yanomami que, intencionalmente, obviava seus corpos napë e um grupo de napë yai inatos: os militares e outros funcionários brancos. Diferenças internas entre yanomami "civilizados" e yanomami "de verdade" foram obviadas para produzir uma diferença máxima com respeito aos napë. Os interlocutores enfatizavam, no discurso, sua yanomami-dade, ao mesmo tempo em que precisavam reter atributos dos brancos (uso do espanhol, documentos escritos, vestimentas) para desempenhar o papel de mediadores - tanto ao traduzir a perspectiva yanomami para os militares e funcionários, quanto ao mostrar aos demais Yanomami sua capacidade de negociar com os brancos. Os interlocutores estabelecem uma continuidade moral com os Yanomami presentes por meio de sua "performance yanomami", no plano do discurso, mas se diferenciam deles exibindo conhecimentos e corpos napë. Essa distribuição ecoa àquela discutida, quando os Yanomami de Ocamo, nas comunidades rio acima, adotam igualmente atitudes e corpos napë, mas mantêm uma continuidade moral com os waikasi, operando, em prol destes últimos, a mediação com os médicos.

\section{Perspectivas indígenas e não-indígenas}

Afirmei, anteriormente, que os brancos ocupam, para os Yanomami, o espaço dos afins potenciais. Eles encarnam a ambigüidade de, ao mesmo tempo, serem provedores dos bens e conhecimentos necessários para produzir pessoas yanomami/napë, mas também representarem o perigo da produção e disseminação de doenças — além de não serem plenamente confiáveis. Se isso corresponde à afinidade potencial inata para os Yanomami, vale a pena colocar a questão simétrica; a saber, a de como os Yanomami se encaixam no mundo dos missionários e médicos.

Todos os médicos rurais que conheço vêem as clínicas do alto Orinoco como lugares de trabalho muito desorganizados. Eles atribuem a maior parte dessa desorganização aos próprios Yanomami, cujo comportamento lhes parece caótico: eles não esperam sua vez; não seguem instruções; 
chegam em grupos e ficam em cima dos médicos enquanto estes últimos trabalham; facilmente ignoram combinações feitas em reuniões e, por último, há sempre um setor da aldeia que tenta constantemente servir-se dos valiosos recursos da clínica: barco, motor e, especialmente, a gasolina, sempre escassa. Furtos ocasionais e artimanhas freqüentes mantêm os médicos em alerta permanente.

Nessas circunstâncias, a orientação normal dos médicos em seu contato com os Yanomami concerne muito mais à produção de convenções para assegurar um ambiente em que se possa viver e trabalhar do que à administração de desacordos com respeito a teorias biomédicas e indígenas da doença ou a terapias. "Instáveis", "imprevisíveis", "cada um faz como bem entende", são algumas das expressões empregadas para definir os Yanomami, seja como pacientes, seja como colegas de trabalho. Diante de tal entropia, os médicos gastam muito tempo e esforço em empreendimentos 'coletivizantes': estabelecendo horários, definindo regras de trabalho com o pessoal de saúde yanomami, fixando normas de acesso aos recursos da clínica etc. Isso é feito no trabalho diário da clínica e também em reuniões comunitárias. A semelhança com a situação que Viveiros de Castro descreveu por meio da expressão "a inconstância da alma selvagem" é, a meu ver, significativa.

O contexto do encontro entre médicos brancos e os Yanomami condensa a distribuição inversa do dado e do artificial a que me referi anteriormente. Como diz Wagner:

Um povo que diferencia deliberadamente [os Yanomami], sendo esta a forma de sua ação, irá invariavelmente contra-inventar uma coletividade motivante [uma ordem social da qual os brancos fazem parte] como "inata", e um povo que coletiviza deliberadamente [os médicos] irá contra-inventar uma diferenciação motivante dessa maneira [os Yanomami desorganizados] (Wagner 1981:51).

Em suma, se os médicos entram no mundo Yanomami como afins potenciais, parte de um todo social convencional e inato, os Yanomami entram no mundo dos médicos como uma particularidade natural, parte da própria natureza. Eles resistem às intenções mútuas e se convertem na motivação uns dos outros.

Aqui reside, penso, um importante princípio gerativo dessa relação índios-brancos. Recordemos que os missionários e outros emissários do Estado, médicos incluídos, são, freqüentemente, os primeiros promotores da "civilização" entre os índios. Eles também estão interessados em algum tipo de processo de "virar brancos". E no entanto, ao passo que os Yanomami tomam a "civilização" como uma forma de diferenciação deli- 
berada (a produção de pessoas duais branco-indígenas, contra o pano de fundo de uma sociedade dada), missionários e médicos tomam-na como uma coletivização deliberada de um substrato entrópico: os brancos não reconhecem a existência de uma sociedade entre os índios e vêem-se assim compelidos a 'fazer' a convenção e a sociedade.

Essas orientações inversas parecem-me fundamentais. A maior parte do tempo, permanecem de tal modo imperceptíveis que, naqueles aspectos que interessam a ambos, índios e brancos equivocam-se uns sobre os outros sem dar-se conta. Preocupações mútuas como a de "civilizar" constituem o locus primário do que podemos chamar "desacordos homônimos" (Viveiros de Castro 2002b), pois é precisamente a homonímia que oculta os interesses e significados diversos de brancos e índios. Para além disso, penso que o desacordo homônimo de "virar civilizado" é provavelmente um meta-mal-entendido gerativo do caráter de muitos cenários interétnicos.

No interior desse desacordo, entretanto, vários outros desacordos homônimos podem ser encontrados. Basta evocar, aqui, as abordagens divergentes de Vilaça (1999) e Conklin (1997) quanto ao papel do corpo em cenários interétnicos. A primeira sublinha o modo como a relevância do corpo na política identitária enraiza-se, em parte, no papel desse corpo na sociopolítica da identidade e alteridade em um universo perspectivista; a segunda, a considera uma estratégia de auto-representação que incorpora valores ocidentais de estética corporal para produzir efeitos políticos. Está claro que o corpo ocupa um lugar crucial em ambas cosmologias - nisto reside a homonímia - mas o desacordo permanece, na medida em que este lugar é bastante distinto. Mencionei também aqui a afinidade entre a ética Yanomami de "não deixar as pessoas sofrerem" e as imagens que os brancos têm dos índios como "pobres" ou "desamparados".

\section{Conclusões}

Comecei afirmando que os brancos, no alto Orinoco, tendem a ver os Yanomami "civilizados" como pessoas culturalmente deterioradas, meio termo entre índios e brancos, sem ser nem uma coisa, nem outra. Tentei mostrar como, ao contrário, o processo de "virar branco" mantém importantes continuidades com outras formas de devir-Outro, e que, enquanto uma forma de diferenciação, é, com efeito, um processo "realmente indígena". Tentei mostrar como um eixo de transformação em branco pode ser visto enquanto uma inovação do espaço convencional ameríndio, retendo muitas de suas características. Ambas as proposições sugerem 
inúmeras reservas diante de análises que resumem tudo isso sob a rubrica da "mudança histórica".

Um aparato teórico como o aqui mobilizado, que permita analisar índios e brancos uns nos termos dos outros, e por meio de uma única linguagem, parece-me útil. A combinação dos conceitos gerais da teoria do simbolismo de Wagner e dos conceitos mais específicos do americanismo parece fornecer uma caixa de ferramentas teórica adequada para analisar os contextos diversos que emergem entre os grupos indígenas da região, no que diz respeito a suas relações com a sociedade mais ampla e o Estado.

Algumas implicações metodológicas podem também ser apontadas. Primeiro, essa análise da complementaridade entre a diferenciação tal como se dá nas partes alta e baixa do rio ressalta a necessidade de, em nosso esforço para captar as práticas cotidianas e a significância do envolvimento com o Estado, ir além da interface índios-brancos e investigar as redes que unem diferentes categorias de pessoas. Em segundo lugar, a análise da maneira como índios e brancos penetram os mundos uns dos outros enquanto formas do inato ilustra a importância de investigações antropológicas simétricas, que focalizem simultaneamente a perspectiva de índios e brancos, observando o papel que desempenham em sua mútua constituição. Isso talvez nos revele, para além de uma reverberação de imagens de brancos e índios — como discutida por Taussig (1987) e Albert (1993) —, o modo como essas perspectivas motivam-se mutuamente a agir uma sobre a outra.

Procurei oferecer algumas idéias passíveis de generalização para outras partes da Amazônia. Estou consciente, não obstante, da vasta diversidade da região, e do fato de que essas idéias podem iluminar alguns casos e não outros. Resta ainda verificar onde estão e quais são os pontos comuns, e onde são inaplicáveis. Será por meio de uma combinação de casos etnográficos tanto congruentes quanto divergentes que poderemos iluminar a extensão de nossa "teoria tradicional" em seu próprio contexto de "transformação em branco".

Recebido em 20 de março de 2004

Aprovado em 07 de maio de 2004

Tradução de Marcela Coelho de Souza

José Antônio Kelly é PhD em Antropologia Social pela Universidade de Cambridge, UK e coordena, atualmente, o "Plano de Saúde Yanomami" do Ministério da Saúde e Desenvolvimento Social da Venezuela. E-mail: <jak29@cam.ac.uk> 


\section{Notas}

* Gostaria de agradecer aos estudantes e professores do PPGAS/ Museu Nacional/ UFRJ por seus comentários, por ocasião do seminário no qual este trabalho foi originalmente apresentado (em março de 2004). Sou igualmente grato a Marcela Coelho de Souza pela leitura dedicada e pela tradução deste artigo.

${ }^{1}$ Esse censo computou 13.347 Yanomami no estado do Amazonas (Colchester e Watson 1995:8). Todavia, 5.882 não foram computados, mas apenas estimados. Um novo censo foi realizado em 2001, mas seus resultados não estavam ainda disponíveis quando da redação deste artigo.

2 Ver Overing (1983-1984), quanto ao argumento geral referente à necessidade da combinação correta de diferenças para a produção da vida social; Viveiros de Castro (1992), para a proposição de que o "inimigo" é o "centro de uma sociedade sem centro", em sua análise do material tupinambá e araweté; Turner (1991:295), para o processo kayapó de transformação da natureza (exterior) em aldeia socializada (interior); McCallum (2001), para a complementaridade kaxinawá entre agência masculina, que troca com o perigoso exterior para obter seus produtos, e agência feminina, que transforma esses produtos em "gente de verdade"; e Fausto (2000), para a dependência de sonhos sobre Outros situados além do círculo do parentesco para a aquisição dos cantos de inimigo, essenciais para a reprodução social no caso dos Parakanã.

${ }^{3}$ Gow (2001) retrata com fineza a combinação desses ingredientes na visão que os Piro têm de seu envolvimento com os brancos. Ver também Rival (2002:161-163), para uma discussão similar do lugar do corpo e de seus novos hábitos (dieta, práticas de higiene, estilo de vida sedentário) no "virar civilizado" — sempre em relação a um outro — entre os Huaraoni do Equador.

${ }^{4} \mathrm{O}$ mito em questão trata da diferenciação entre grupos humanos. Com a ascensão das águas canibais, que ameaçam matar os antigos, alguns sobem o monte Mãiyõ para salvar-se. As águas carregam com elas muitos Yanomami. Quando as águas recedem, depois do sacrifício de uma velha que é nelas atira$\mathrm{da}$, esses Yanomami carregados pelas águas se transformam em brancos, outros índios, outros grupos yanomami etc (esse resumo baseia-se em Lizot 1975:35). Esta é a origem dos crioulos, segundo me contaram muitos moradores de Ocamo e de rio acima. 
${ }^{5} \mathrm{Na}$ análise de Albert do parentesco Yanomam (Ramos e Albert 1977:82), o termo yayë marca a importante distinção entre os cognatos "reais" (consangüíneos e afins reais) e os "apenas parentes", "aqueles que estão ligados, no espaço genealógico comum, por uma fratria situada mais remotamente que na segunda geração ascendente e, nessa medida, esquecida". Esses "meros parentes" são reclassificados como afins potenciais. Em uma formulação posterior, Albert (1985:221-235) retém a essência desse argumento. Lizot (1977:59), escrevendo sobre os Yanomami, argumenta que o termo yaiyë, ao lado de mashi, "mesma classe, tipo, lado de algo", designa germanos e primos paralelos. Seu uso define uma parentela bilateral que reconhece um ancestral masculino comum. Lizot (1971:26) refere-se ao verbo yai- ara, diferenciar meio-irmãos; a forma também se refere à co-residência com parentes mashi (ver também Lizot 2005:490). Seja como for, é importante notar sua função de marcador de uma maior proximidade e similaridade no contexto do parentesco.

${ }^{6}$ Os pontos no interior de cada esfera estão ali para expressar um certo grau de heterogeneidade. Há casos isolados de pessoas que vivem rio acima e que foram mais expostas a instituições mestiças, destacando-se assim em suas comunidades. Esses indivíduos tornam-se mediadores-chave quando das visitas de médicos e outro mestiços. Por outro lado, em Ocamo, alguns velhos e outros são menos versados em assuntos mestiços do que a maioria, e podem ser vistos como "tradicionalistas". Embora eu não discuta essa questão nem aqui, nem em minha tese, é importante notar que as mulheres viajam para fora do Alto Orinoco muito menos do que os homens. Em Ocamo, era também comum que elas deixassem a escola antes dos homens (por volta da $4^{\mathrm{a}}$. série), para casar-se. Em geral, as mulheres têm menos contato com mestiços, uma esfera da política reservada principalmente aos homens. McCallum (2001) explora essas diferenças e examina a complementaridade homens-mulheres de maneira bastante efetiva.

${ }^{7}$ Parcialmente, na medida em que Turner, embora enfatize a continuidade da ordenação sociocêntrica do cosmos, concentra sua análise apenas na interface kayapó /brancos, perdendo de vista essa qualidade de rede que estou descrevendo, discutida por autores como Gow (1993), Carneiro da Cunha (1998) e Hugh-Jones (1992).

${ }^{8}$ Carneiro da Cunha (1998) descreve essa mesma transformação - de um isomorfismo igualitário para uma rede de dominação - no contexto da rede de dívidas e créditos da borracha, no Brasil Ocidental do início do século XX (rio JuruáManaus-Belém-Europa).

${ }^{9}$ No vídeo que fiz deste evento, o discurso do velho não me é totalmente compreensível. O que fica claro, no entanto, é que a tradução se alinha mais com os 
argumentos avançados pelos mediadores do que com o conteúdo real da fala do velho. Como argumentarei adiante, as ações dos guerreiros e dos mediadores do protesto são mutuamente complementares. Os primeiros visualmente, os segundos verbalmente, estão ambos empenhados na mesma "performance yanomami".

\section{Referências bibliográficas}

ALBERT, Bruce. 1985. Temps du sang, temps de cendres: représentation de la maladie, système rituel et espace politique chez les Yanomami du sud-est (Amazonie brésilienne). PhD Dissertation, Université de Paris $\mathrm{X}$.

. 1988. "La fumée du métal: histoire et représentations du contact chez les Yanomami (Brésil)". L'Homme, 106-107:87-119.

.1993. "L'or cannibal et la chute du ciel". L'Homme, 126-128:349-378.

ALÈS, Catherine. 2000. "Anger as a marker of love: the ethic of conviviality among the Yanomami". In: J. Overing e A. Passes (orgs.), The anthropology of love and anger: the aesthetics of conviviality in native Amazonia. London: Routledge.

CARNEIRO DA CUNHA, Manuela. 1998. "Pontos de vista sobre a floresta Amazônica: xamanismo e tradução". Mana. Estudos de Antropologia Social, 4(1):7-22.

COLCHESTER, Marcus e WATSON, Fiona. 1995. Venezuela: violaciones de los derechos indígenas. Chadlington: World Rainforest Movement \& Survival International.
CONKLIN, Beth. 1997. "Body paint, feathers, and vcrs: aesthetics and authenticity in Amazonian activism". American Ethnologist, 24 : 711-737.

DESCOLA, Phillippe. 1997. The spears of twilight: life and death in the Amazon jungle. London: HarperCollins.

FAUSTO, Carlos. 2000. "Of enemies and pets: warfare and shamanism in Amazonia". American Ethnologist, 26:933-956.

GOW, Peter. 1993. "Gringos and wild indians: images of history in western amazonian cultures". L'Homme, 126-128:327-347.

. 1994. "River people: shamanism and history". In: N. Thomas e C. Humphrey (orgs.), Shamanism history \& the state. Ann Arbor: University of Michigan Press. . 2001. An amazonian myth and its history. Oxford: Oxford University Press. (Oxford studies in social and cultural anthropology).

HUGH-JONES, Stephen. 1992. "Yesterday's luxuries, tomorrow's necessities: business and barter in Northwest Amazonia". In: C. Humphrey e S. Hugh-Jones (orgs.), Barter, ex- 
change and value: an anthropological approach. Cambridge: Cambridge University Press.

KELLY, José Antonio. 2001. "Fractalidade e troca de perspectivas". Mana. Estudos de Antropologia Social, $7(2): 95-132$.

LIZOT, Jacques. 1971. "Remarques sur le vocabulaire de parenté Yanomami". L'Homme, 11:25-38.

. 1975. El hombre de la pantorrilla preñada. Caracas: Fundación la Salle de Ciencias Naturales.

. 1977."Descendance et affinité chez lesYanomami: antinomie et complémentarité". Paper presented to the Actes du 42 Congrès International des Américanistes.

. 1994. "Words in the night: the ceremonial dialogue - one expression of peaceful relationships among the Yanomami". In: L. Sponsel e T. Gregor (orgs.), The anthropology of peace and nonviolence. London: Lynne Rienner Publishers.

. 1996. Introducción a la lengua Yanomami: morfología. Caracas: Escuela Técnica Popular Don Bosco. . 1998. "Situación cultural y acción sanitaria: el caso Yanomami". La Iglesia en Amazonas, 81-82:30-36. 2005. Diccionario enciclopédico de la lengua Yanomami. Caracas: Vicariato Apostólico de Puerto Ayacucho.

McCALLUM, Cecilia. 2001. Gender and sociality in Amazonia: how real people are made. Oxford: Berg.

OVERING, Joanna. 1983-4. "Elementary structures of reciprocity: a com- parative note on Guianese, Central Brazilian, and North-West Amazon socio-political thought". Antropológica, 59-62:331-348.

RAMOS, Alcida e ALBERT, Bruce. 1977. "Yanoama descent and affinity: the Sanumá/Yanomam contrast". Paper presented to the Actes du 42 Congrès International des Américanistes.

RIVAL, Laura. 2002. Trekking through history: the Huaorani of amazonian Ecuador. New York: Columbia University Press. (The Historical Ecology Series).

STRATHERN, Marylin. 1990. "Artefacts of history: events and the interpretation of images". In: J. Siikala (ed.), Culture and history in the Pacific. Helsinki: The Finish Anthropological Society.

. 1999. Property, substance and effect: anthropological essays on persons and things. London: Althon Press.

TAUSSIG, Michael. 1987. Shamanism, colonialism and the wild man: a study in terror and healing. Chicago: University of Chicago Press.

TORO, Martin. 1997. "Economía y salud en el Amazonas venezolano". In: J. Chiappino e C. Alès (orgs.), Del microscopio a la maraca. Caracas: Editorial Ex Libris.

TURNER,Terrence. 1987. "From cosmology to ideology: resistance, adaptation and social consciousness among the Kayapo". Trabalho apresentado na reunião da $\mathrm{ABA}$ Associação Brasileira de Antropologia, Belém do Para. 
1991. "Representing, resisting, rethinking: historical transformations of Kayapo culture and anthropological consciousness". In: G. Stocking (org.), Colonial situations: essays on the contextualization of ethnographic knowledge. Madison: University of Wisconsin Press.

TUZIN, Donald e GREGOR, Thomas. 2001. Gender in Amazonia and Melanesia: an exploration of the comparative method. Berkley: University of California Press.

VILAÇA, Aparecida. 1999. "Devenir autre: chamanisme et contact interethnique en Amazonie brésilienne". Journal de la Societé des Américanistes, 85:239-60. . 2002. "Making kin out of others in Amazonia". Journal of the Royal Anthropological Institute, 8:347-365.

VIVEIROS DE CASTRO, Eduardo. 1992. From the enemy's point of view: humanity and divinity in an amazonian society. Chicago: University of Chigaco Press. 1993. "Alguns aspectos da afinidade no dravidianato amazônico". In: E. Viveiros de Castro e M. Car- neiro da Cunha (orgs.), Amazônia: etnologia e história indígena. São Paulo: NHII/ FAPESP. . 1998. "Perspectivism in Amazonia and elsewhere". Cambridge conferences. Cambridge. Ms. 2001. "Gut feelings about Amazonia: potential affinity". In: L. Rival e N. Whitehead (orgs.), Beyond the visible and the material: the amerinidianization of society in the work of Peter Rivière. Oxford: Oxford University Press. . 2002a. A inconstância da alma selvagem - e outros ensaios de antropologia. São Paulo: Cosac \& Naify. 2002b. "O nativo relativo". Mana. Estudos de Antropologia Social, 8(1):113-148.

WAGNER, Roy. 1978. Lethal speech: Daribi myth as symbolic obviation. Ithaca: Cornell University Press. . 1981. The invention of culture. Chicago: University of Chicago Press. . 1986. Symbols that stand for themselves. Chicago: University of Chicago Press. 


\section{Resumo}

O artigo descreve e analisa alguns aspectos da transformação que ocorre entre os Yanomami na Venezuela como produto da crescente troca com a sociedade nacional, em particular com o sistema médico. Procura-se mostrar como muitos aspectos da vida moderna e contemporânea Yanomami só podem ser compreendidos a partir de conceitos da antropologia amazônica, desenvolvidos em contextos mais tradicionais, conceitos como o de 'afinidade potencial'. Explorando a natureza do espaço sociopolítico contemporâneo, de como a interação entre brancos e Yanomami sustenta tal espaço e tornando explícitas as formas indígenas de ser e viver que se mantêm nessa transformação e troca com os brancos, oferecemos algumas reflexões que podem ser úteis na análise das situações de contato étnico em diferentes partes da Amazônia e com diferentes agentes dos estados nacionais.

Palavras-chave Yanomami, Amazonas, Mudança histórica, Teoria antropológica amazônica, Relação índio-branco

\section{Abstract}

This article describes and analyses various aspects of the transformation occurring among the Yanomami in Venezuela, a product of their increasing exchanges with national society and in particular the medical system. The article looks to show how many aspects of Yanomami contemporary and modern life can only be understood by employing concepts from Amazonian anthropology, such as 'potential affinity,' developed in more traditional contexts. By exploring the nature of contemporary sociopolitical space and how the interaction between Whites and Yanomami sustains this space, making explicit the very indigenous ways of being and living that persist through transformation and exchange with Whites, the article tackles issues which may be useful in the analysis of ethnic contact situations in other parts of Amazonia and involving different national state agents.

Key words Yanomami, Amazonia, Historical Change, Amazonian Anthropological Theory, Indian-White relations 